Original Article

\title{
PHOENIX DACTYLIFERA FRUIT EXTRACT AMELIORATES ALTERED BIOCHEMICAL PARAMETERS IN STREPTOZOTOCIN-INDUCED DIABETES MELLITUS ALBINO RATS
}

\author{
OGO A. 0. ${ }^{*}$, ABAH S. F. ${ }^{2}$, INALEGWU B. ${ }^{2}$, ERU U. E. ${ }^{3}$ \\ ${ }^{1}$ Department of Medical Biochemistry, College of Health Sciences, Benue State University, Makurdi, ${ }^{2}$ Department of Biochemistry, College \\ of Science, University of Agriculture Makurdi, ${ }^{3}$ Department of Physiology, College of Health Sciences, Benue State University Makurdi
}

*Email: oogo@bsum.edu.ng

Received: 18 Aug 2020, Revised and Accepted: 05 Sep 2020

\begin{abstract}
Objective: Consistent projections have indicated a steady increase in the global burden of diabetes mellitus. Given the increased cost in conventional management of the condition in addition to reported side effects and cost of orthodox management, attention is shifting to the use of alternative methods such as plants materials with dual benefits as food and medicine. Thus, this study was designed to investigate the effect of date palm fruit on some biochemical parameters in streptozotocin-induced wistar rats.

Methods: Animals were divided into 5 groups of 6 rats each (I as normal control, II as diabetic control and 3-5 as extract-treated groups) maintained for $14 \mathrm{~d}$. At the end of the treatment, the animals were fasted overnight, then sacrificed and blood samples collected for analysis of biochemical parameters (including blood glucose, blood lipids and enzymes).

Results: The results show that treatment of diabetic animals with extract of date palm fruit show a significant $(\mathrm{P}<0.05)$ reduction in glucose levels in groups II-V compared to group I. Similar positive effects were observed in the levels of lipids and enzymes in treated groups compared to diabetic control group II. A GC-MS analysis of the fraction of the fruit extract revealed some bioactive compounds that may be responsible for the effects exhibited in the study.
\end{abstract}

Conclusion: These findings which demonstrate the ameliorative effect on hyperglycemia and hyperlipidemia, further support the use of date palm fruit as a nutraceutical agent.

Keywords: Phoenix dactylifera, Diabetes mellitus, Hypoglycemic, Hypolipidemic, Fruit extract, Nutraceutical

(C) 2020 The Authors. Published by Innovare Academic Sciences Pvt Ltd. This is an open access article under the CC BY license (http://creativecommons.org/licenses/by/4.0/) DOI: http://dx.doi.org/10.22159/ijcpr.2020v12i6.40275. Journal homepage: https://innovareacademics.in/journals/index.php/ijcpr

\section{INTRODUCTION}

Diabetes mellitus (DM) is a group of metabolic diseases characterized by hyperglycemia resulting from defects in insulin secretion, insulin action, or a combination of the two [1]. High blood glucose levels or hyperglyceamia are a major feature of this disease condition as a consequence of inadequate pancreatic insulin secretion or poor insulin-directed mobilization of glucose by target cells. Diabetes mellitus is often aggravated by and associated with metabolic complications, manifesting overtime to damage of organs such as the kidney, eye, heart, blood vessels and nerves, and if not properly managed could subsequently lead to premature death. Such complications on organs may arise due to derangements in the regulatory systems for storage and mobilization of metabolic fuels [2], including carbohydrates, lipids and proteins occasioned by aberrant metabolic processes. Based on aetiology and clinical presentation, diabetes mellitus can be broadly classified as type 1(T1DM which results from the destruction of pancreatic beta cells leading to absolute or near-absolute insulin deficiency); type 2 (T2DM-caused by progressive insulin secretory defect arising from insulin resistance); gestational (that occurs during the second or third trimester of pregnancy; hybrid form (which include slowly evolving immunemediated diabetes of adults and ketosis-prone type 2 diabetes) as well as other specific types (including monogenic defects in $\beta$-cell function and in insulin action occasioned by genetic mutations) [3, 4]. Type 1diabetes represents only a small fraction of the total burden of diabetes in a population, although it is the major type of diabetes in younger age groups at the majority of developing countries. Unfortunately, the incidence of type 1 diabetes is increasing in both self-sustaining and dependent countries across the globe, and it is projected to occur in children even at earlier ages than the current situation if both palliative and other management strategies remain unchanged On the other hand, a much higher percentage of the population across nations are riddled with the burden of type 2 diabetes, with developing countries bearing the greater brunt owing to poor healthcare services. Long-term complications of diabetics include retinopathy, neuropathy and nephropathy accompanied by an increased risk of other forms of health challenges spanning cardiovascular, peripheral vascular and cerebrovascular diseases. Disturbing reports document that the global burden of diabetes is steadily increasing, reaching over 400 million adult patients worldwide in 2014 according to the world health organization (WHO) On the other hand, the International Diabetes Federation estimates that greater than a million children and adolescents have become diabetic [5]. These fig. are projected to rise astronomically to over 600 million adults if synergistic intervention strategies backed by committed Government policies are not adopted as a matter of urgency. In sub-Saharan Africa, the burden of diabetes is high, with Nigeria as a major contributor. Indeed, the results of a meta-analysis conducted in Nigeria in 2017 put every part of the country at risk of diabetes, with overall prevalence rising to $5.7 \%$ from previously documented $4.9 \%$ [6]. Part of the current interventions are the use of hypoglycemic chemicals, which may be out of reach of every sufferer, particularly those from poor resource settings such as sub-Saharan Africa. This justifies a clarion call to intensify the use of alternative natural remedies that have evolved long before now $[7,8]$ but with rather sketchy scientific evidence. These include various antidiabetic plants and plant products such as date palm.

Date palm (Phoenix dactylifera $L$ ), a monocotyledonous, perennial tree belonging to the family Arecaceae (Palmae) and genera Phoenix (Coryphoideae phoeniceae) with about 14 different species. It is extensively cultivated in Northern Asia and Africa for its edible fruit and seed for folklore medicine [9]. In Nigeria, the date fruit is commonly called Dabino, among the Northerners, where it is mostly commonly consumed, and the name has been adopted by nonnortherners nationally. The plant records more than 2000 different species and have been used for food for close to a thousand years [10]. Date is rich in phytochemicals such as sterols, phenolics, carotenoids, procyanidins, anthocyanins, flavonoids, glycosides, and tannins [11, $12]$, concentration of which is dependent on the stage of fruit picking, 
species, location and soil conditions. In addition to consumption as food, date palm fruits are traditionally used to prepare a wide range of different products such as date juice concentrates (spread, syrup and liquid sugar), fermented date products (wine, bioethanol, vinegar, organic acids) and date pastes for bakery and confectionary use [13]. Contrary to documented evidence on the use of date palm in food application, reports of its use for medicinal purposes is limited, although there are paltry studies that have beamed their searchlight in this area, especially on the seed [14,15], leaving much to be done with the fruit. Giving the global call to halt the rise in diabetes and obesity by the year 2025 by health organizations, and the high cost of managing the condition with conventional drugs, concerted efforts in finding cost-effective, nutritionally beneficial alternatives for treatment or management is key in achieving this target. Thus, this study was carried out to evaluate the effects of date palm fruit extract on liver enzymes as well as glucose and lipid levels of experimental models of diabetes mellitus induced by streptozotocin.

\section{MATERIALS AND METHODS}

\section{Collection of plant material and extraction process}

Dried date fruits of uniform size and free of physical damage were purchased from Wadata market in Makurdi metropolis of Benue State. Taxonomical identification and authentication of the plant material were done by Omoche Ojobo of the Department of Botany, University of Agriculture, with voucher number (FUAM/BOT/0033) deposited at the University herbarium. The dried fruits were washed and air-dried in the laboratory under ambient temperature. The dried fruits were ground into a fine powder and preserved in moisture-free, airtight laboratory containers for the next stage. The powdered plant material (400 g) was defatted using petroleum ether before extraction with methanol using Soxhlet apparatus for $48 \mathrm{~h}$. The extract was evaporated to complete dryness with a rotary evaporator and kept refrigerated for use in subsequent experiments. The crude extract was fractionated by subjecting it to column and thin layer chromatographic techniques following standard protocols. Similar fractions on TLC plates were pooled together on the basis of the molecular size of spots into fractions 1 and 2 . In order to determine the bioactive compounds present in the date palm fruit, fraction 2 (chosen based on the result of the effect of glucose levels) was further analysed by Gas chromatography-mass spectrometry (GC-MS) (Model GC 7890B, MSD 5977A, Agilent Tech).

\section{Experimental animal models and design}

Thirty (30) male albino rats weighing between $200 \mathrm{~g}-250 \mathrm{~g}$ were acquired from the Animal House of the College of Health Sciences, Benue State University, Makurdi. They were maintained under standard conditions (temperature of $25 \pm 2{ }^{\circ} \mathrm{C}, 40-50 \pm 5 \%$ humidity with $12 \mathrm{~h}$ light/12 h dark cycle) for acclimatization in the Animal House of Department of Biochemistry, University of Agriculture, Makurdi for $1 \mathrm{w}$ while allowing them free access to standard feeds (Chikum feed PLC, Lagos, Nigeria), and water ad libitum. Procedures for animal care and use were followed according to institutional guidelines provided by the University. The animal grouping consisted of six rats per group designated as follows:

Group I: Normal Non-diabetic Control (NNDC)-not induced, not treated

Group II: Diabetic Untreated (DU)-animals were not induced by STZ and were not treated with either fruit extract or standard drug

Group III: Diabetic, Treated with Crude Extract (DTCE)-animals were induced by STZ and treated with $400 \mathrm{mg} / \mathrm{kg}$ BW crude extract of date palm fruit.

Group IV: Diabetic, Treated with Fraction 1 (DTF1)-animals were induced by STZ and treated with $400 \mathrm{mg} / \mathrm{kg}$ BW fraction 1 of date palm fruit extract.
Group V: Diabetic, Treated with Fraction 2 (DTF2)-animals were induced by STZ and treated with $400 \mathrm{mg} / \mathrm{kg}$ BW fraction 2 of date palm fruit extract.

\section{Experimental induction of diabetes, treatment and preparation of samples}

The animals in groups II-V were injected after a $24 \mathrm{~h}$ fasting with a single intraperitoneal dose of streptozotocin (STZ) (Pharmacia, New Jersey, USA) at $45 \mathrm{mg} / \mathrm{kg}$ BW dissolved in normal saline, while group I received only the vehicle. Fasting blood glucose levels of the rats were tested $72 \mathrm{~h}$ post-induction and animals meeting the criterion of having blood glucose level $>200 \mathrm{mg} / \mathrm{dL}$ were considered diabetic and included in the study and treated as indicated in the group description above for $14 \mathrm{~d}$. The animals' weight, eating habits and water intake were periodically recorded throughout the treatment period. At the end of the experiment, a $20 \%$ glucose solution $(2 \mathrm{~g} / \mathrm{kg}$ BW) was administered through a polyethylene gastric tube to the rats, which were sacrificed after anesthetized with chloroform and cardiac puncture performed at different intervals to obtain blood samples into plain bottle (without anticoagulant) and processed for biochemical analyses.

\section{Toxicity test}

Acute toxicity and lethality of the extract and fractions were carried out using the method originally described by [16]. Rats were orally given 200,400 and $1000 \mathrm{mg} / \mathrm{kg}$ of each extract and fraction. The animals were observed individually and regularly for behavioural changes and general toxicity signs or death for $24 \mathrm{~h}$. No mortality was recorded either for the short or long period, so $400 \mathrm{mg} / \mathrm{kg}$ was chosen as a treatment concentration similar to previous study [17].

\section{Biochemical assays}

Blood samples collected in separate test tubes were centrifuged at 300 rpm for $10 \mathrm{~min}$ and serum obtained was used for the following biochemical measurements. Oral glucose tolerance test (OGTT) performed at the end of the experimental week following a $24 \mathrm{~h}$ fast, was carried out through measurement of blood glucose concentrations using blood glucose test strips and glucometer (ACCU-ANSWER). Determination of Aspartate Aminotransferase (AST), Alanine Aminotransferase (ALT), Alkaline Phosphatase (ALP) was carried out according to standard protocols. Serum levels of Triglycerides (TG), High Density Lipoprotein (HDL), Low-Density Lipoprotein (LDL) and Total Cholesterol (TC) were determined colorimetrically with RANDOX Diagnostic assay kit (Randox Laboratories, UK) following manufacturer's protocol using JENWAY 7305 UV-visible spectrophotometer.

\section{Statistical analysis}

Data generated were subjected to statistical analysis using the SPSS software version 20 (SPSS, Inc., Chicago, USA). All data are presented as mean \pm standard deviation (SD) using one-way ANOVA followed by Duncan's multiple post hoc test for comparison. Statistical significance was established at $\mathrm{P}$ value $<0.05$.

\section{RESULTS}

Effect of $P$. dactylifera fruit extract treatment on glucose level of streptozotocin-induced diabetic rats

The results of the glucose level of both control and diabetic rats before and after induction/treatment with crude extract and purified fractions of $P$. dactylifera is presented in table 1 . The results revealed that both the crude extract and fraction significantly $(\mathrm{P}<0.05)$ reduced glucose levels of treated animals in groups III-V compared to diabetic control group II.

Table 1: Effect of $P$. dactylifera fruit extract and fractions on glucose level of streptozotocin-induced diabetic rats

\begin{tabular}{lll}
\hline & Glucose level before treatment & Glucose level after treatment \\
\hline GROUP I & $101.943 \pm 4.733^{\mathrm{a}}$ & $93.280 \pm 4.079^{\mathrm{a}}$ \\
GROUP II & $223.533 \pm 4.185^{\mathrm{b}}$ & $239.533 \pm 4.185^{\mathrm{e}}$ \\
GROUP III & $221.430 \pm 1.786^{\mathrm{b}}$ & $216.766 \pm 2.161^{\mathrm{d}}$ \\
GROUP IV & $222.756 \pm 3.566^{\mathrm{b}}$ & $210.926 \pm 3.379^{\mathrm{d}}$ \\
GROUP V & $218.313 \pm 4.472^{\mathrm{b}}$ & $187.310 \pm 2.223^{\mathrm{c}}$ \\
p-value & 0.001 & 0.001 \\
\hline
\end{tabular}

Values are presented as mean \pm SD for 3 determinations. Values with different superscript across the row are statistically significant at $\mathrm{p} \leq 0.05$ ). 
KEY: Grp I: Normal Control; Grp II: Diabetic Control; Grp III: Diabetic, treated with crude extract; Grp IV: Diabetic, treated with Fraction 1; Grp V: Diabetic, treated with Fraction 2.

Effect of $\boldsymbol{P}$. dactylifera fruit extract treatment on liver enzymes of streptozotocin-induced diabetic rats

The effect of treatment of $P$. dactylifera fruit extract on hepatic enzymes of experimental animals are as shown in table 2 . The result show a significant $(\mathrm{P}<0.05)$ reduction in the levels of AST and ALP but not ALT between normal control rats and diabetic rats and between diabetic animals and treated one.

Effect of $P$. dactylifera fruit extract treatment on serum lipid profile of streptozotocin-induced diabetic rats

As shown in table 3, there were significant changes in the levels of blood lipid profile. The HDL was significantly $(\mathrm{P}<0.05)$ increased from about $33 \mathrm{mg} / \mathrm{dl}$ in the diabetic control group to greater than 60 $\mathrm{mg} / \mathrm{dl}$ in group $\mathrm{V}$ with marginal increases in groups III and IV. In the same vein, there was a significant reduction in the level of total cholesterol between diabetic control group and across all treated groups in similar fashion to the other lipids tested.

GC-MS analysis result of $P$. dactylifera fruit extract showing bioactive compound

Gas chromatography-mass spectrometric analysis of fraction 2 of $P$. dactylifera fruit extract showing the mass spectra is presented in fig. 1 , while the identified bioactive compounds is as shown in table 4 The fragmentation patterns of the mass spectra by peaks were compared with those of the known compounds stored in the National Institute of Standards and Technology (NIST) research library (result not included). The analysis revealed some bioactive compounds reputable for various chemical actions, including tissue repair, hypocholesterolemic and hypoglycemic effect in addition to antioxidant activity.

Table 2: Effect of $P$. dactylifera fruit extract and fractions on liver enzymes of streptozotocin-induced diabetic rats

\begin{tabular}{llll}
\hline Group & AST $(\boldsymbol{\mu l})$ & ALT $(\mu \mathrm{l})$ & ALP( $\boldsymbol{\mu l})$ \\
\hline Grp I & $31.20 \pm 5.63^{\mathrm{a}}$ & $33.60 \pm 7.16^{\mathrm{a}}$ & $33.06 \pm 21.98^{\mathrm{a}}$ \\
Grp II & $51.80 \pm 7.73^{\mathrm{c}}$ & $59.20 \pm 4.09^{\mathrm{b}}$ & $135.86 \pm 5.51^{\mathrm{d}}$ \\
Grp III & $42.40 \pm 2.01^{\mathrm{b}}$ & $54.40 \pm 1.82^{\mathrm{b}}$ & $117.42 \pm 3.89^{\mathrm{c}}$ \\
Grp IV & $42.80 \pm 1.92^{\mathrm{b}}$ & $52.40 \pm 2.70^{\mathrm{b}}$ & $119.16 \pm 14.29^{\mathrm{c}}$ \\
Grp V & $43.40 \pm 3.05^{\mathrm{b}}$ & $53.60 \pm 2.41^{\mathrm{b}}$ & $68.30 \pm 26.8^{\mathrm{b}}$ \\
\hline
\end{tabular}

Values are presented as mean \pm SD for 3 determinations. Values with different superscript down the group are statistically significant at $\mathrm{p} \leq 0.05$ ).

Table 3: Effect of $P$. dactylifera fruit extract and fractions on serum lipid profile of streptozotocin-induced diabetic rats

\begin{tabular}{|c|c|c|c|c|}
\hline Group & HDL-C(mg/dl) & TAG(mg/dl) & T-CHL(mg/dl) & LDL-C(mg/dl) \\
\hline Grp I & $73.32 \pm 8.99^{d}$ & $91.80 \pm 34.50^{a}$ & $103.70 \pm 41.10^{\mathrm{a}}$ & $71.14 \pm 11.68^{\mathrm{a}}$ \\
\hline Grp II & $33.10 \pm 4.57^{a}$ & $188.40 \pm 23.20^{\mathrm{d}}$ & $209.90 \pm 8.07 \mathrm{e}$ & $143.83 \pm 6.50^{\mathrm{d}}$ \\
\hline Grp III & $49.49 \pm 10.68^{b}$ & $113.80 \pm 39.10^{\mathrm{b}}$ & $138.60 \pm 39.30^{\mathrm{b}}$ & $119.31 \pm 10.85^{c}$ \\
\hline Grp IV & $45.40 \pm 6.63^{\mathrm{b}}$ & $123.50 \pm 33.20^{c}$ & $149.60 \pm 40.90^{c}$ & $98.92 \pm 12.12^{\mathrm{b}}$ \\
\hline Grp V & $66.92 \pm 11.77^{c}$ & $103.10 \pm 38.30^{\mathrm{b}}$ & $163.30 \pm 35.70^{\mathrm{d}}$ & $102.94 \pm 18.49^{b}$ \\
\hline
\end{tabular}

Values are presented as mean \pm SD for 3 determinations. Values with different superscript down the group are statistically significant at $\mathrm{p}<0.05$ ).

Table 4: Bioactive compounds of $P$. dactylifera fruit extract revealed by GC-MS analysis

\begin{tabular}{|c|c|c|c|c|c|c|}
\hline Name of compound & RT & Molecular formula & MW & Peak area \% & Bioactivity & Structure \\
\hline L-Valinol & 9.948 & $\mathrm{C}_{5} \mathrm{H}_{13} \mathrm{NO}$ & 103 & 3.1 & Tissue repair & \\
\hline DL-Arabinitol & 10.217 & $\mathrm{C}_{5} \mathrm{H}_{12} \mathrm{O}_{5}$ & 152 & 1.0 & Antibacterial, anticandida & \\
\hline N-Hexadecanoic acid & 31.411 & $\mathrm{C}_{16} \mathrm{H}_{32} \mathrm{O}_{2}$ & 256 & 16.4 & $\begin{array}{l}\text { Hypocholesterolemic, antioxidant } \\
\text { activities }\end{array}$ & \\
\hline Xylitol & 10.217 & $\mathrm{C}_{5} \mathrm{H}_{12} \mathrm{O}_{5}$ & 152 & 1.0 & $\begin{array}{l}\text { Hypoglycemic activity, reduce insulin } \\
\text { response }\end{array}$ & \\
\hline Resorcinol,2-acetyl & 21.661 & $\mathrm{C}_{8} \mathrm{H}_{8} \mathrm{O}_{3}$ & 152 & 0.9 & Antiseptic, antibacterial & \\
\hline Serinol & 9.936 & $\mathrm{C}_{3} \mathrm{H}_{9} \mathrm{NO}_{2}$ & 91 & 4.7 & $\begin{array}{l}\text { Anticancer, intermediate of } \\
\text { chloramphenicol production }\end{array}$ & \\
\hline D-Arabinitol & 10.217 & $\mathrm{C}_{5} \mathrm{H}_{12} \mathrm{O}_{5}$ & 152 & 1.0 & Hypoglycemic activity & \\
\hline D-glycero-d-ido-hepose & 12.935 & $\mathrm{C}_{7} \mathrm{H}_{14} \mathrm{O}_{7}$ & 210 & 2.9 & Anti-inflammatory, antiseptic activity & \\
\hline $\begin{array}{l}\text { 9-octadecanoic } \\
\text { acid,methyl ester,(E)- }\end{array}$ & 33.757 & $\mathrm{C}_{19} \mathrm{H}_{36} \mathrm{O}_{2}$ & 296 & 7.2 & Antimicrobial, anti-inflammatory & W \\
\hline $\begin{array}{l}\text { Cycloheptasiloxane, } \\
\text { Tetradecamethyl- }\end{array}$ & 21.661 & $\mathrm{C}_{14} \mathrm{H}_{42} \mathrm{O}_{7} \mathrm{Si}_{7}$ & 518 & 0.9 & Antimicrobial activity & \\
\hline 9-octadecanoic acid(E)- & 34.667 & $\mathrm{C}_{18} \mathrm{H}_{34} \mathrm{O}_{2}$ & 282 & 67.0 & Anti-inflammatory, antimicrobial & WMY \\
\hline
\end{tabular}




\section{CHROMATOGRAM}

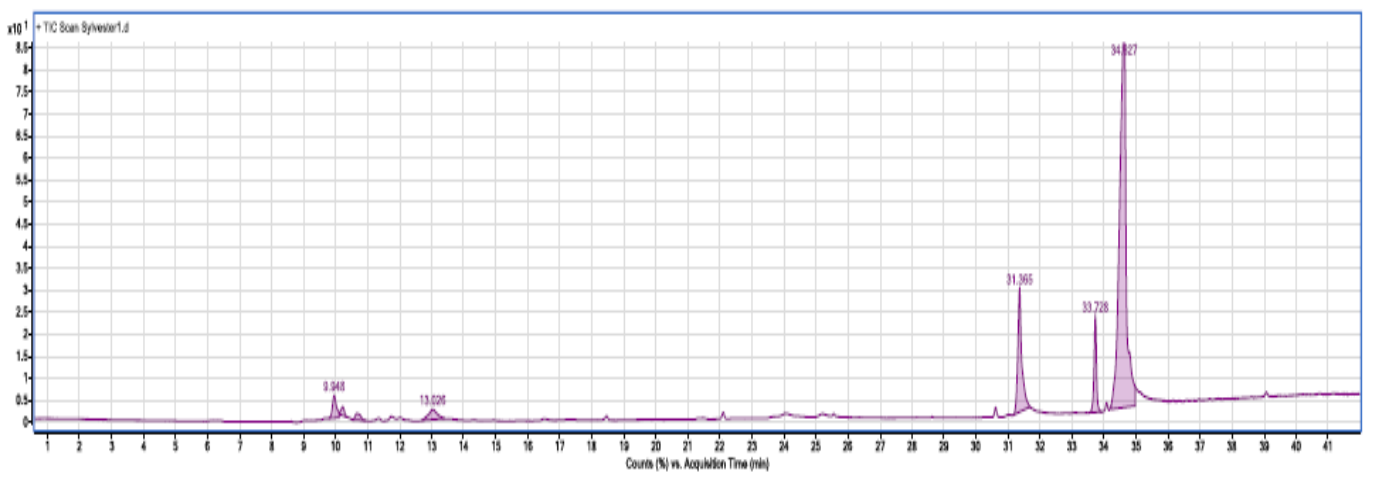

Fig. 1: GC-MS chromatogram of $P$. dactylifera fraction

\section{DISCUSSION}

Experimentally induced animal models have made possible the study of the pathophysiology of many disease conditions, including diabetes mellitus, with the view to getting an improved understanding that would enhance the development of promising therapeutic interventions. Two commonly used chemical agents for inducing type 1 diabetes in laboratory animals are alloxan and streptozotocin, both of which target the destruction of beta cells of pancreatic islets through different mechanisms, making glucose handling difficult in such cells/organisms. However, in this study, we utilized streptozotocin, which has been reported to be more tissuespecific and increased inductive capacity with less toxicity. To determine the effectiveness of the protocol, we tested the glucose levels of the animals $72 \mathrm{~h}$ post-induction. The results clearly showed a significant increase $(\mathrm{p}<0.05)$ in glucose levels (hyperglycemia) as well as body weight (result not shown) of the induced animal in groups II, III and IV and V compared to their control counterparts in group I (table 1). These results are consistent with previous reports that utilized the same inductive chemical agent [18, 19], indicating the robustness of the technique in successfully creating a diabetic condition in most strains of rodents, among other animal models used, probably through destruction of the pancreatic beta cells of the islets of Langerhans [20]. The hypoglycemic effect of the date fruit extract shows significant decline in the mean glucose level of treated animals compared with the diabetic control, indicating the ability of the extract in restoring the ability of the animals to manage glucose fluctuations arising from induction. This is in agreement with similar effects shown by Thai medicinal plant analysed for use as a control agent for diabetic model animal [21]. An investigation into the chemicals that may be responsible for the sugar-managing property demonstrated in the extract through GC-MS analysis showed various bioactive compounds, including hypocholesterolemic $\mathrm{N}$ Hexadecanoic acid and amino acid derivative L-valinol previously demonstrated to have tissue-proliferative ability [22]. Additionally, the analysis revealed the presence of 'safe' sugar such as xylitol and arabinitol, which have a low glycemic index as alluded to in previous studies across different varieties of date palm [23]. This makes them suitable for the management of sugar levels, as they do not potentiate any risky postprandial glucose excursions [24]. Although the exact mechanisms of how date palm fruit ameliorates the surge in glucose level following streptozotocin induction is unknown and a focus of future research, it may not be unconnected with these identified compounds whose potency has been severally documented but in other context.

Liver marker enzymes, including amino transferases, are usually found at low levels intracellularly as a result of normal cellular metabolism; however, their levels become elevated in certain conditions indicative of cellular damage and subsequent release into the bloodstream, which forms the basis for clinical analysis cum medical diagnosis. In particular, liver disease for instance, is accompanied with increased levels of AST and ALT, which may be due to damage to the liver cells, and have also been documented as hallmarks of diabetes mellitus [25]. Our findings show elevated levels of these marker enzymes in the experimental rats compared to the normal control group, consistent with similar reports of increase in hepatic enzymes in hyperglycemic animals treated with streptozotocin [26, 27]. However, injection of date fruit extract attenuated the rise by significantly reducing the levels of these enzymes in diabetic-treated groups compared with control. This finding also concurs with those reported for effects of isolates from date pericarp on alloxan-induced diabetes in rats [28], suggesting the effectiveness of date fruit in taming diabetic-induced alterations in experimental animals. ALT plays an important role in gluconeogenesis and amino acid metabolism by catalyzing the transamination reaction involving L-alanine and $\alpha$-ketoglutarate to form pyruvate and L-glutamate, and thus its homeostasis probably influenced by the chemical composition of date palm may be a compensatory response to depletion of substrate for these metabolic pathways.

Alterations in serum lipid profile occasioned by streptozotocininduced diabetes in the experimental rats were ameliorated upon treatment with the fruit extract, akin to the findings of [29], which indicates the hypolipedemic effect of date palm and a potential to delay development of coronary heart disease that usually characterizes diabetic-related complications. Diabetic hyperlipidemia is featured with enhanced Triacylglycerides, Total Cholesterol, Low-Density Lipoprotein, and decreased High-Density Lipoprotein cholesterol levels. These changes impose an increased risk for coronary heart disease in patients with DM. Low-Density Lipoprotein-C (LDL-C) positively and High-Density Lipoprotein-C (HDL-C) negatively correlate with the risk of cardiovascular disease $[30,31]$. The significant antihyperlipidemic activity of the fruit of $P$. dactylifera in this study may be attributed to the presence of its various phytochemical constituents, some of which are revealed by the GC-MS analysis as a plausible analytical means of identifying bioactive components of the fruit. Since oxidative stress is implicated as a causative factor in the pathogenesis of diabetes, recent approaches focus on the role of oxidative stress in pancreatic ? damage [32], and hence antioxidants such as date palm may have a true antidiabetic effect via antioxidant potential. It has been suggested that antidiabetic action of date palm may occur through inhibition of carbohydrate metabolizing enzymes such as pancreatic ?-amylase [33], which may decrease starch breakdown and offers good postprandial glycemic control. Also, antidiabetic action could be due to the stimulation of insulin release from residual ?-cells or protection of functional ?-cells from further atrophy by antidiabetic active constituents that may act individually or synergistically [34, 35].

\section{CONCLUSION}

This study has demonstrated the sugar-lowering effect of date palm fruit extract and fractions, which is the clinical goal of diabetic management; thus it could be a promising alternative in the treatment of hyperglycemia-a hallmark of diabetes. In addition, the date palm fruit extract showed a significant positive influence on altered lipid levels associated with diabetes. We also showed that 
date pal fruit attenuates increased levels of hepatic enzymes, all of which may be due to the initiation of repairs of damaged $\beta$-cell tissues following stretozotocin injection by bioactive compounds it contains. Giving that diabetic condition is associated with some abnormal antioxidant status proteins in addition to lipid peroxidation, the focus of our next endeavor would be to investigate the impact of the fruit on intracellular antioxidant systems in order to understand the antidiabetic mechanism of the date palm fruit.

\section{FUNDING}

Nil

\section{AUTHORS CONTRIBUTIONS}

OAO Conceived, designed, validated analytical protocols, supervised experiments, interpreted results and edited the first draft manuscript. ASF Participated in experimental design, carried out experiments and wrote the first draft manuscript. IB Participated in experimental design, validated and supervised experiments. EUE Participated in validating experimental procedure and interpreted results. All authors approved the manuscript for submission.

\section{CONFLICT OF INTERESTS}

Declared none

\section{REFERENCES}

1. Mestry SN, Dhodi JB, Kumbhar SB, Juvekar AR. Attenuation of diabetic nephropathy in streptozotocin-induced diabetic rats by Punica granatum linn. leaves extract. J Tradit Complement Med 2016;7:273-80.

2. Piero MN, Nzaro GM, Njagi JM. Diabetes mellitus-a devastating metabolic disorder. Asian J Biomed Pharm Sci 2014;4:1-7.

3. American Diabetes Association (ADA). Classification and Diagnosis of Diabetes. Diabetes Care 2015;38:S8-S16.

4. World Health Organization (WHO). Classification of Diabetes Mellitus. Geneva; 2019. p. 2-29.

5. International Diabetes Federation (IDF). Diabetes Atlas. 8th Edition. Brussels; 2017.

6. Uloko AE, Musa BM, Ramalan MA, Gezewa ID, Puepet FH, Uloko AT, et al. Prevalence and risk factors for diabetes mellitus in nigeria: a systematic review and meta-analysis. Diabetes Ther 2018;9:1307-16.

7. Piero NM, Njagi MJ, Kibiti MC, Ngeranwa JN, Njagi NM, Eliud NM. Wilson GK. Herbal management of diabetes mellitus: a rapidly expanding research avenue. Int J Curr Pharm Res 2012;4:1-4.

8. Rehan T, Khalid IK, Rizwan AM, Zafeer NW. Natural remedies for diabetes mellitus. Int Curr Pharm J 2016;5:97-102.

9. Alkaabi JM, Al-Dabbagh B, Ahmad S, Saadi HF, Gariballa S, Al Ghazali M. Glycemic indices of five varieties of dates in healthy and diabetic subjects. Nutr J 2011;10:59.

10. Eoin LN. Systematics: blind dating. Nat Plants 2016;2:16069.

11. Mohamed RMA, Fageer ASM, Eltayeb MM, Ahmed IAM. Chemical composition, antioxidant capacity, and mineral extractability of sudanese date palm (Phoenix dactylifera L.) fruits. Food Sci Nutr 2014;2:478-89.

12. Oni SO, Abiola MA, Ladokun OA, Ighodaro OM, Oyedele OM. Nutritional and phytochemical profile of niger cultivated date palm (Phoenix Dactilyfera L). J Food Nutr Sci 2015;3:114-8.

13. Yahaya SA, Ahmed FO, Gana SA, Daudu OA, Yusuf ABM, Osaroodin PE, et al. Nutritional properties of some selected date palm (Phoenix dactylifera L) landraces in nigeria. World J Food Sci Technol 2020;4:1-7.

14. Yahaya SA, Omokhudu CA, Abdulahi MA, Sanusi MK. Phytochemical screening and mineral evaluation of fresh date fruits (Phoenix dactylifera L.) in wet season of Nigeria. J Agric Crop Res 2015;3:47-52.

15. Hafez El-Far JA, Shaheen HM, Abd El-Daim M, Al Jaouni SK, Mousa JSA. Date palm (Phoenix dactylifera): protection and remedy food. Curr Trends Nutr 2016:1:2.
16. Saryono S. Date seeds drinking as antidiabetic: a systematic review IOP conf. series: Earth and Environmental Science; 2019. p. 255.

17. Abiola MA, Oni SO, Olusola AL, Osasenaga MI, Omotayo MO. Nutritional and phytochemical profile of niger cultivated date palm (Phoenix Dactilyfera L). J Food Nutr Sci 2015;3:114-8.

18. Akbarzadeh AD, Norouzian MR, Mehrabi SH, Jamshidi A, Farhangi A, Allah Verdi SMA, et al. Induction of diabetes by streptozotocin in rats. Indian J Clin Biochem 2007;22:60-4.

19. Furman BL. Streptozotocin-induced diabetic models in mice and rats. Curr Protoc Pharmacol 2015;70:47-54.

20. Deeds MC, Anderson JM, Armstrong AS, Gastineau DA, Hiddinga HJ, Jahangir A. Single-dose streptozotocin-induced diabetes: considerations or study design in islet transplantation models. NLLab Anim 2011;45:131-40.

21. Chaimum Aom A, Chomko S, Talubmook C. Toxicology and oral glucose tolerance test (OGTT) of thai medicinal plant used for diabetes controls, phyllanthus aci-dus L. (Euphorbiaceae). Pharmacogn J 2017;9:58-61.

22. Bexfield AB, Morgan AE, Wagstaff CJ, Newton RP, Ratcliffe NA, Nigam Y. Amino acid derivatives from Lucilia sericata excretions/secretions may contribute to the beneficial effects of maggot therapy via increased angiogenesis. $\mathrm{Br} J$ Dermatol 2010;162:554-62.

23. AlGeffari MA, Almogbel ES, Alhomaidan HT, El-Mergawi R, Barrimaha IA. Glycaemic indices, glycaemic load and glycaemic response for seventeen varieties of dates grown in Saudi Arabia. Ann Saudi Med 2016;36:397-403.

24. El-Mousalamy AMD, Hussein AAM, Mahmoud SA, Abdelaziz A, Shaker G Aqueous. Methanolic extracts of palm date seeds and fruits (Phoenix dactylifera) protects against diabetic nephropathy in type ii diabetic rats. Biochem Physiol 2016;5:205

25. Shibabaw T, Dessie G, Molla MD, Zerihun MF, Ayelign B. Assessment of liver marker enzymes and its association with type 2 diabetes mellitus in Northwest Ethiopia. BMC Res Notes 2019;12:707.

26. Fernandes AAH, Barbosa EL, Novelli AF. Junior and cristiano machado galhardi effect of naringerin on biochemical parameters in the streptozotocin-induced diabetic rats. Brazilian Arch Biol Technol 2009;52:51-9.

27. Mathur S, Mehta DK, Kapoor S, Yadav S. Liver function in type-2 diabetes mellitus patients. Int J Sci Stud 2016;3:43-7.

28. Michael HN, Salib JY, Eskander EF. Bioactivity of diosmetin glycosides isolated from the epicarp of date fruits, phoenix dactylifera, on the biochemical profile of alloxan diabetic male rats. Phytother Res 2012;14:1-6.

29. Hasan M, Mohieldein A. In vivo evaluation of anti-diabetic, hypolipidemic, antioxidative activities of saudi date seed extract on streptozotocin-induced diabetic rats. J Clin Diagnostic Res 2016;10:6-12.

30. El-Mergawi RA, AlGeffari MA, Al-Humaid A. Sugar types, phenolic contents, and antioxidant activities for 17 Saudi Arabian date cultivars and their relations with glycemic indices. Int J Fruit Sci 2018 https://doi.org/10.1080/15538362.2018.1535356

31. Ayatollahi SA, Sharifi Rad M, Roointan A, Baghalpour N, Salehi B, Shinwari ZK, et al. Antidiabetic activity of date seed methanolic extracts in alloxan-induced diabetic rats. Pak Vet J 2019;39:583-7.

32. Gerber PA, Rutter GA. The role of oxidative stress and hypoxia in pancreatic beta-cell dysfunction in diabetes mellitus. Antioxidants Redox Signaling 2017;26:501-17.

33. Sudha P, Smita SZ, Shobha YB, Kumar AR. Potent $\alpha$-amylase inhibitory activity of Indian Ayurvedic medicinal plants. BMC Complement Altern Med 2011;5:11-5.

34. Oyedemi SO, Adewusi EA, Aiyegoro OA, Akinpelu DA. Antidiabetic and haematological effect of aqueous extract of stem bark of Afzelia africana (Smith) on streptozotocin-induced diabetic wistar rats. Asian Pac J Trop Biomed 2011;1:353-8.

35. Ahmed S, Khan RA, Subia J. Antihyperlipidemic and hepatoprotective effects of native date fruit variety "Aseel" (Phoenix Dactylifera). Pak J Pharm Sci 2016;29:1945-50. 